\title{
Employees Behaviour, Equity in Financial Compensation and Performance of Public Universities in Ghana
}

\author{
Evelyn Owusu Frempong ${ }^{1} \&$ Gabriel Dwomoh ${ }^{2, *}$ \\ ${ }^{1}$ Department of Management and General Studies, Christian Service University College, Ghana \\ ${ }^{2}$ Institute of Entrepreneurship and Enterprise Development, Kumasi Technical University, Ghana \\ *Correspondence: Institute of Entrepreneurship and Enterprise Development, Kumasi Technical University, Ghana. \\ E-mail: gabdwumoo@yahoo.com
}

\author{
Received: July 7, $2017 \quad$ Accepted: July 22, $2017 \quad$ Online Published: July 27, 2017 \\ doi:10.5430/mos.v4n3p43 URL: https://doi.org/10.5430/mos.v4n3p43
}

\begin{abstract}
The main purpose of the study is to contribute to knowledge by assessing the moderating role equity in financial compensation plays on the relationship between employees' behavior and performance of state owned universities in Ghana. The targeted population for the study was the 10 public universities established by an Act of Parliament and are recognized by the National Accreditation Board. Out of this, 7 public universities were selected using convenience sampling. The choice of this sampling method was based on accessibility and easy access to information to facilitate the research. In each of the sample, 15 employees' mainly senior members both from administration and academic totalling 105 were randomly selected for the study. The main instrument used for collection of primary data was questionnaires and interviews whilst review of selected public universities websites, published textbooks, journals and newsletters constitute the secondary data. The instrument used for the study was tested for its reliability and fitness and the result was positive with cronbach's alpha value of 0.856 . Analysis for the study was done using correlation and regression to test for the hypotheses developed. The results show that employees' behaviour has high positive relationship with performance of public universities with equity in financial compensation playing a moderating role. The study therefore recommends the need for the Government of Ghana to continue with the full implementation of its single spine pay policy since it will ensure fairness in the public sector wage which will in turn influence employees' behaviour positively and performance of the sector as a whole.
\end{abstract}

Keywords: public universities; financial compensation; equity; employees' behaviour; performance

\section{Introduction}

A well formulated and implemented financial compensation strategy is expected to influence employees' behavior. Despite this, the relationship between employees' behaviour and organizational performance is influenced by how equitable the organization rewards its employees. According to Smith (1963) if an employee feels underpaid, it will result in the employee feeling hostile towards the organization as well as his or her own colleagues and this may result in the employee not performing well at work anymore. Incentive systems are so important that it has the tendency of influencing employee behaviour (Hall 2000). Lin (2000) added that an effective financial compensation system can stimulate employees to work harder thereby increasing productivity and firm performance. This means for organizations to get employees to put up their best, it is important for them to consider the rewards they have in place for their employees.

If employees are dissatisfied as a result of inequity in organizations pay systems, there is a high tendency for misconduct to occur on the part of the employees. According to Larkin et al (2012), misconduct includes several types of behaviours that are counterproductive to the firm. To the writers, they are actions that are explicitly illegal; violate formal organizational rules as well as the spirit of the rules. Normally employees engage in this misconduct because they believe it will increase their utility or happiness. That is to say misconduct is the compensation of inequity in the pay systems of organizations. Zenger (1994) corroborated by Lazear (2000) affirmed that equality in compensation has a strong relationship with the rate of labour turnover in organizations. That is the motivation of employees to join, stay or leave an organization depends not only how attractive its reward systems are but how fair those rewards are 
in comparison with people who perform similar jobs. Again Carrell and Dittrich, (1978) in support of Zenger (1994) and Lazear (2000) used equity theory to explain the consequences of inequality in organizations compensation. According to the writers, the main consequence of an inequitable financial compensation system involves negative reactions of employees and this may involve quitting the organization and looking for an organization that promotes equity in rewarding its employees.

Geurts et al (1999) literature was in conformity with assertions made by Carrell and Dittrich (1978), Zenger (1994) and Lazear (2000) that inequity in organization compensations have strong relationship with negative behaviour of employees and as such special attention should be given to it. To the writers, if an employee perceives inequity in an organization's reward systems, it generates a negative emotional state and this in turn triggers withdrawal reactions which possibly can lead to organizations experiencing high rate of labour turnover. Paik et al (2007) are among the writers who also used equity theory to explain the consequences of inequity in organizations pay systems. The writers examined the behaviour of host country nationals compensation in relation to the compensation given to parent or third country nationals and concluded that the perceived compensation gaps between these different categories of workers create a lot of job dissatisfaction on the part of the host country nationals. These compensation gaps often results in hostile relationship among expatriates and host country nationals which in turn affects productivity. Talking about the good side of equity in an organization's financial compensation, studies conducted by Hopenhayn (1992) had proven a positive relationship between equity in employees' compensation and survival of organizations. According to the writer, over forty percent of firms in manufacturing disappear over five year periods and had to be replaced by new ones because of the lack of commitment on the part of employees due to unfairness in their compensation. Lin (2014) used a diagram to illustrate the direct relationship between equity in compensation and organizational commitment as well as employment stability. The writer's research findings was in line with that of Zenger (1994) which was corroborated by Lazear (2000) that the propensity for employees to stay long in organizations largely depends on how fairly they have been treated when it comes compensation issues. Zaman et al (2011) adding their voice to the relationship between equity in financial compensation and employees performance also pointed out that there is a positive relationship between extrinsic rewards and employee motivation and hence performance. The writers were of the view that despite this positive relationship, the major challenge is that most employers are not offering fair and adequate financial rewards to their employees

Drawing a clue from the good side of equity in organizations financial compensation and the numerous problems associated with inequity in organizations compensation systems, the Government of Ghana as way of improving public sector performance introduced the universal pay system which was referred to as the single spine salary structure (SPSS). According to the International Monetary Fund (2016), the purpose of the Ghana Government introducing the SPSS was to ensure fiscal sustainability, simplify bargaining, better connect pay and productivity and more importantly increase equity among public sector workers. The question that needs to be asked is that has equality in compensation of public sector workers in Ghana influence their behaviour and performance of state institutions particularly public universities? Whilst answering this question, it is important to know as pointed out by Osibanjo et al (2012), that there have been several studies on the relationship between organizations financial compensation packages and employees behaviour but very few of these studies focus on how equality in financial compensation plays a moderating role between employee behaviour and performance of organizations in the public sector especially state owned universities. It is therefore necessary to look at how the rectifications in distortions of Ghana public universities financial compensation systems had influenced both lecturers and administrative staff behaviour and the general performance of these universities as a whole.

\section{Conceptual Framework and Hypotheses for the Study}

The literature review has shown a positive relationship between equity in organizations financial compensation and performance as well as employees behaviour. From the literature review, the researchers developed a conceptual framework for the study by concentrating on stated owned universities in Ghana as can be seen in figure 1 below: 


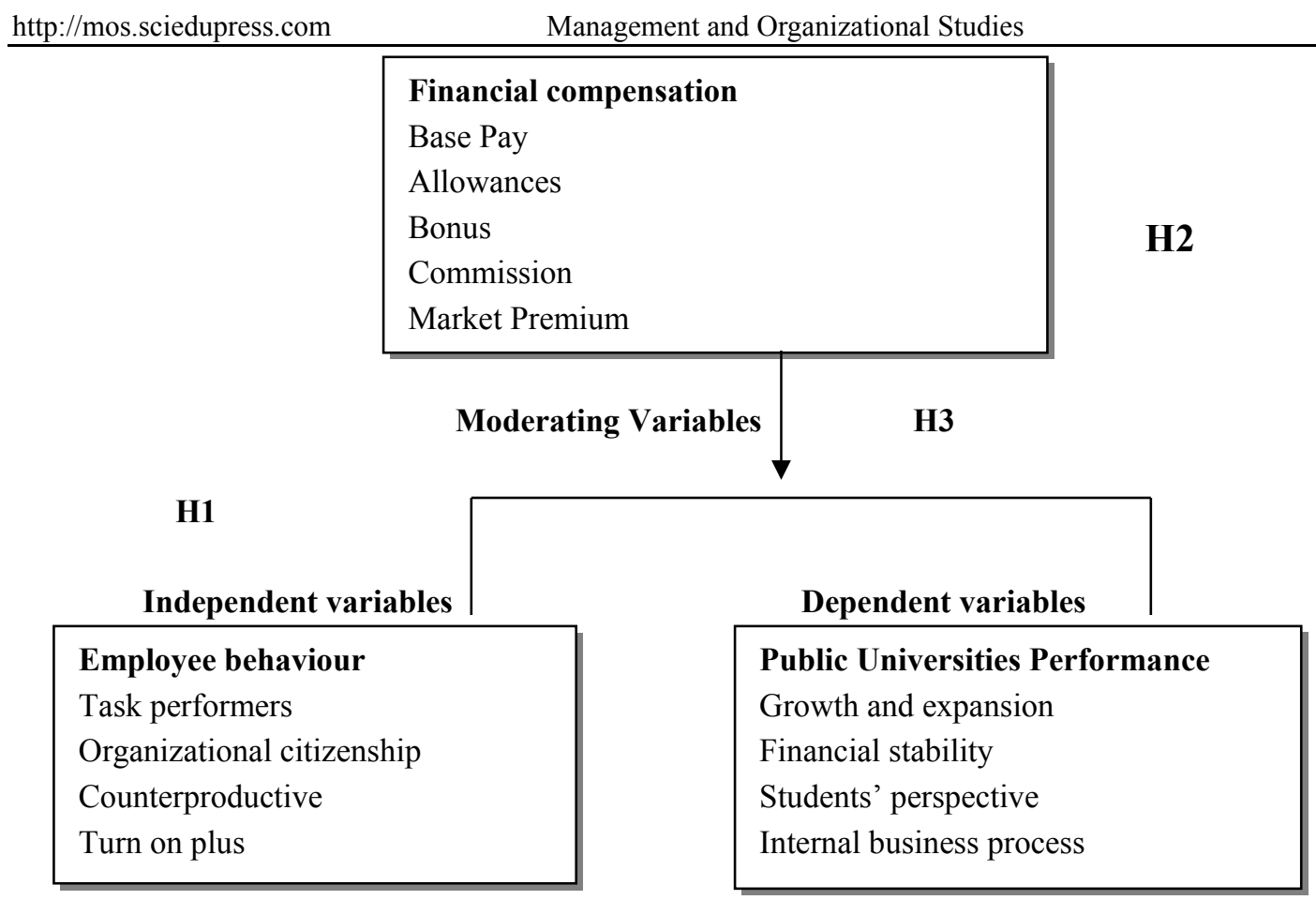

Figure 1. Independent, Dependent and Moderating Variables of the Study

Source: Researchers own construct 2016

Looking at the figure above, employees behaviour constitute independent variables whilst performance of public universities is the dependent variable. Financial compensation was used as the moderating variables. From the literature review and the conceptual framework developed, the researchers came out with the hypotheses of the study as follows:

Hypothesis 1: There is significant relationship between employees' behaviour and performance of public universities

Hypothesis 2: There is significant relationship between equity in financial compensation and performance of public universities

Hypothesis 3: There is moderating effect of equity in financial compensation on the relationship between employees' behaviour and performance of public universities.

\section{Methodology Adopted for the Study}

Since the study is on finding the relationship between different set of variables, the researchers found it appropriate to adopt a cross- sectional research approach. According to Seyedian and Yi (2011), cross-sectional research approach is appropriate when finding relationships between variables at one moment in time. To the writers, cross-sectional designs focus on studying and drawing inferences from existing differences between people, subjects, or phenomena. The target population of the study is the 10 public universities that had been recognized by the Ghana National Accreditation Board as posted on their website www.nab.gov.gh. Using convenience sampling based on accessibility to information, 7 public universities were selected as the sample for the study. In each of the sample, 15 employees' mainly senior members both from administration and academic totaling 105 were randomly selected for the study. The instruments that were used to collect primary data were questionnaires and interviews that seek to solicit employees view on the Government of Ghana implementation of single spine salary structure meant to remove unfair disparities in public sector wage and its influence on employees' behaviour as well the performance of these universities. Out of a total of 105 questionnaires that were distributed to the selected sample, the researchers were able to collect 97 but 95 of them were meaningful for data extraction and analysis. For the purpose of the study, employees' behaviour, performance of the selected public universities and equity in financial compensation were defined using the variables depicted in figure 1 above. Again, the researchers used correlation analysis to check the 
nature and direction of relationships of the variables whilst regression analysis was also adopted to establish mathematical models and to test for hypotheses formulated. The researchers also used Analysis of Variance (ANOVA) to determine whether there were any statistically significant differences between the means.

Information obtained from journals, institutional websites, published books and newsletters constitute the main source of secondary data. Lastly, in testing for reliability of the instruments used, cronbach's alpha was calculated for 17 item questionnaire which the value was 0.856 . This proves that the instrument was reliable and can be used for the study.

\section{Presentation of Results and Findings}

The main objective of the study is to examine the relationship between employees behaviour ad performance of public universities in Ghana with equity in financial compensation of these universities playing a moderating role. In order to establish the relationship between employees' behaviour and public universities performance, correlation and regression analyses were performed by the researchers based on the primary data collected. In order to obtain composite variables for the independent variables, the researchers aggregated all the data obtained from the different public universities after which Pearson's Product Moment Correlation (r) was computed as shown in tables 1 and 2.

Table 1. Correlations between Employees' Behaviour and Performance of Public Universities

\begin{tabular}{lll}
\hline & & Universities Performance \\
\hline Universities Performance & Pearson Correlation & 1 \\
& Sig. (2-tailed) & \\
& $\mathrm{N}$ & 95 \\
Task Performers & Pearson Correlation & $.809^{* *}$ \\
& Sig. (2-tailed) & .000 \\
& $\mathrm{~N}$ & 95 \\
Organizational Citizens & Pearson Correlation & $.843^{* *}$ \\
& Sig. (2-tailed) & .000 \\
Counter Productive & $\mathrm{N}$ & 95 \\
& Pearson Correlation & $.872^{* *}$ \\
Turn-on plus & Sig. (2-tailed) & .000 \\
& $\mathrm{~N}$ & 95 \\
Employees Behaviour & Pearson Correlation & $.962^{* *}$ \\
& Sig. (2-tailed) & .000 \\
& $\mathrm{~N}$ & 95 \\
& Pearson Correlation & $.868^{* *}$ \\
& Sig. (2-tailed) & .000 \\
& $\mathrm{~N}$ & 95 \\
\hline
\end{tabular}

**. Correlation is significant at the 0.05 level for 2-tail

Source: Primary data, 2016

The computed ' $r$ ' between employees' behaviour and public universities performance shows that there is a high positive relationship between the variables with task performers $(\mathrm{r}=.809)$, organizational citizens $(\mathrm{r}=.843)$, counterproductive $(\mathrm{r}=.872)$ and turn on plus employees $(\mathrm{r}=.962)$ all significant at $\mathrm{p}$ value $(0.000)<0.05$. These means that just like any other organization, the attitude a university worker puts up strongly affects the university in terms of achieving its objectives.

Since one of the objectives of the research was to estimate the relationships among the variables and also to establish equation for the models, regression analysis was performed as can be seen in table 2 . 
Table 2. Regression Analysis and Analysis of Variance on Employees Behaviour and Universities Performance

\begin{tabular}{|c|c|c|c|c|c|c|c|c|c|c|}
\hline & \multicolumn{6}{|c|}{ Standardised } & \multicolumn{2}{|l|}{ Df } & \multicolumn{2}{|l|}{$\begin{array}{l}\text { Collinearity } \\
\text { Statistics }\end{array}$} \\
\hline Regression & B & $\begin{array}{l}\text { Std. } \\
\text { Error }\end{array}$ & & $.924^{\mathrm{a}}$ & .854 & 75.614 & 4 & $.000^{\mathrm{a}}$ & Tolerance & VIF \\
\hline Constant & .387 & .235 & .0328 & & & Residual & 41 & & & \\
\hline Task Performers & .046 & .212 & .0483 & & & & & & 0.074 & 10.3 \\
\hline $\begin{array}{l}\text { Organizational } \\
\text { Citizens }\end{array}$ & .141 & .113 & .0414 & & & & & & 0.094 & 10.7 \\
\hline $\begin{array}{l}\text { Counter } \\
\text { Productive }\end{array}$ & .132 & .117 & .0492 & & & & & & 0.175 & 6.52 \\
\hline Turn on Plus & .483 & .115 & .0488 & & & & & & 0.138 & 5.41 \\
\hline
\end{tabular}

Model is significant at 0.05 level for 2-tail

Source: Primary data, 2016

From the model, collinearity is shown by tolerance and variance inflation factor (VIF) which are close to zero and greater than ten respectively. The VIF helped the researchers to measure how much the variance (the square of the estimates standard deviation) of the estimated regression co-efficient increased because of collinearity.

Looking at the regression model, it can be seen that when each of the independent variables (employees' behaviour) was regressed with the dependent variable (universities performance), organizational citizens $(\mathrm{O})$ was found to be the most significant predictor of public universities performance $\left(\mathrm{Y}_{1}\right)$ with $\mathrm{p}$ value $(0.0414)<0.05$. This was followed by task performers $(\mathrm{P})$ with $\mathrm{p}$ value $0.0483<0.05$. The next significant predictor of universities performance is counterproductive (C) with $\mathrm{p}$ value 0.0492 and lastly turn on plus $(\mathrm{T})$ with $\mathrm{p}$ value 0.0488 . From this, we can deduce that each employee behaviour and public universities performance can be expressed as: $\mathrm{Y}_{1}=0.39+0.05 \mathrm{O}+0.14 \mathrm{P}+$ $0.13 \mathrm{C}+0.48 \mathrm{~T}$. This implies that a positive percentage change in organizational citizens would cause $0.05 \%$ positive change in public universities performance. Similarly, a positive percentage change in task performers would cause $0.14 \%$ change in public universities performance whilst a positive percentage change in counterproductive will cause $0.13 \%$ in public universities performance. Lastly a positive percentage change in turn on plus would cause $0.48 \%$ in public universities performance.

Since the regression model has $\mathrm{F}=75.614$ with all the tolerance values greater than zero and significant number of the VIF are less than ten, one can say that there is significant relationship between the independent variables (employees' behaviour) and the dependent variable (public universities performance) and hence we accept our first hypothesis that there is a significant relationship between employees' behaviour and public universities performance. The result of the study is not surprising to the researchers since performance of public universities are determined by their contribution to research, community service and how they impart knowledge onto students and if these universities can claim good performance in these areas, it largely depends on the sort of behaviour exhibited by majority of their employees. Whilst counterproductive workers are expected to contribute to the universities negatively, those who act as organizational citizens and not spectators go extra mile and perform more than what is expected from them.

In testing for our second hypothesis, regression analysis was performed to estimate the relationships among equity in financial compensation and performance of public universities. This was also done in order to establish equation for the models developed for the study. The regression and analysis of variance on equity in financial compensation and public universities performance can be presented in table 3 . 
Table 3. Regression and ANOVA on Equity in Financial Compensation and Performance of Public Universities

\begin{tabular}{|c|c|c|c|c|c|c|c|c|c|c|}
\hline \multirow[b]{3}{*}{ Regression } & \multirow{2}{*}{\multicolumn{2}{|c|}{ Standardised }} & \multirow[b]{2}{*}{ Sig. } & \multirow{3}{*}{$\frac{\mathrm{R}}{.994 \mathrm{a}}$} & \multirow{3}{*}{$\begin{array}{c}\mathrm{R} \\
\text { Square } \\
.988\end{array}$} & \multicolumn{2}{|r|}{$\mathrm{df}$} & & \multirow{2}{*}{\multicolumn{2}{|c|}{ Collinearity Statistics }} \\
\hline & & & & & & $\mathrm{F}$ & & Sig. & & \\
\hline & B & $\begin{array}{c}\text { Std. } \\
\text { Error }\end{array}$ & & & & 246.152 & 4 & $.000^{\mathrm{a}}$ & Tolerance & VIF \\
\hline Constant & 6.125 & .084 & .000 & & & Residual & 36 & & & \\
\hline Base Pay & 2.481 & .072 & .000 & & & & & & .612 & 8.642 \\
\hline Allowances & 2.632 & .473 & .000 & & & & & & .218 & 5.326 \\
\hline Bonus & 1.675 & .138 & .568 & & & & & & .009 & 15.421 \\
\hline Commission & 1.453 & .086 & .611 & & & & & & .005 & 26.321 \\
\hline Market Premium & 2.735 & .073 & .000 & & & & & & .214 & 8.416 \\
\hline
\end{tabular}

Model is significant at 0.05 level for 2-tail

Source: Primary data, 2016

From the model, when each of the variables for equity in financial compensation was regressed with public universities performance, base pay (BP), allowances (AL) and market premium (MP) were found to be significant predictors of public universities performance with $\mathrm{p}$ values less than 0.05 . On the other hand bonus (BO) and commission $(\mathrm{CO})$ were found to be insignificant predictors of public universities performance. This means bonus and commission has no influence on the behaviour of public university workers which can affect those universities performance. The insignificance of these variables is due to the fact that bonuses and commissions are not part of the compensation packages that are paid to workers in public universities and as such poor implementation of bonus and commission schemes has not influence on how public university workers behave.

From the regression model, each financial compensation and public universities performance can be expressed as: $\mathrm{Y}_{2}$ $=6.12+2.48 \mathrm{BP}+2.63 \mathrm{AL}+1.68 \mathrm{BO}+1.45 \mathrm{CO}+2.74 \mathrm{MP}$. The model shows that a unit positive change in base pay of public university workers would cause $2.48 \%$ increase in public universities performance whilst a unit positive change in allowances would cause $2.63 \%$ increase in performance of these public universities. In the same way, a positive percentage change in bonus would cause $1.68 \%$ increase in performance; a positive percentage change in commission would cause $1.45 \%$ increase and lastly a positive change in market premium would cause $2.74 \%$ increase in performance of these universities. The model clearly shows that base pay, allowances and market premium need to be given proper attention in terms of how fairly they are implemented since they have a greater influence on the performance of these public universities. As can be seen in the model, the square of the multiple correlations calculated $\left(\mathrm{R}^{2}=0.988\right)$ means that equity in financial compensation explains $98.8 \%$ of variation when other variables are held constant. Based on the regression model and the results, we accept our second hypothesis that there is a significant relationship between equity in financial compensation and performance of public universities in Ghana.

The last hypothesis to be tested for the study is whether there is moderating effect of equity in financial compensation on the relationship between employees' behaviour and performance of public universities. The moderator variable (equity in financial compensation) is a variable that affects the strength of the relationship between the dependent (employees' behaviour) and the independent variable (public universities performance). In testing the moderating effect between the variables, a hierarchical multiple regression analysis was conducted by the researchers in order to determine the proportion of variance in public universities performance caused by moderating effect of equity in financial compensation and this is presented in table 4 below:

Table 4. Model Summary and Change Statistics

\begin{tabular}{|c|c|c|c|c|c|c|c|c|c|}
\hline \multirow[b]{2}{*}{ Model } & \multirow[b]{2}{*}{$\mathrm{R}$} & \multirow[b]{2}{*}{$\begin{array}{c}\mathrm{R} \\
\text { Square }\end{array}$} & \multirow[b]{2}{*}{$\begin{array}{l}\text { Adjusted R } \\
\text { Square }\end{array}$} & \multirow[b]{2}{*}{$\begin{array}{l}\text { Std. Error of the } \\
\text { Estimate }\end{array}$} & \multicolumn{5}{|c|}{ Change Statistics } \\
\hline & & & & & $\begin{array}{l}\text { R Square } \\
\text { Change }\end{array}$ & F Change & df1 & df 2 & $\begin{array}{l}\text { Sig. F } \\
\text { Change }\end{array}$ \\
\hline 1 & $.724^{\mathrm{a}}$ & .524 & .516 & .258 & .524 & 116.352 & 4 & 52 & .000 \\
\hline 3 & $.953^{\mathrm{b}}$ & .908 & .902 & .535 & .38 & 124.846 & 1 & 48 & .000 \\
\hline
\end{tabular}

Model is significant at 0.05 level for 2-tail

Source: Primary data, 2016 
From the model above, it can be seen that the change in squared multiple correlation coefficient is 0.38 and this is seen as significant considering that $p$ value $(0.000)<0.05$. This means that equity in financial compensation explain additional $38 \%$ variation in public universities performance. Since changes in ' $F$ ' $=124.346$ and $p$ value $(0.000)<$ 0.05 , one can conclude that there is a significant variation in the model fit and as such we accept our third hypothesis that there is a moderating effect of equity in financial compensation on the relationship between employees' behaviour and performance of public universities. The significance of the results is that although employees' behaviour has positive relationship with performance, there should be a variable that will trigger employees to behave in a certain way. Fairness in compensation systems promoted by the Ghana Government who is seen as the employer in these public universities played the moderating role between the behaviour of employees and performance the universities.

\section{Conclusion}

The study showed a high positive relationship between employees' behaviour and performance of public universities. This means that the Government of Ghana's effort to remove disparities in public sector wage had largely influenced the behaviour of employees positively. Since employees' behaviour are influenced by certain factors, the study also showed that equity in financial compensation plays a moderating role for employees' behaviour to influence the performance of these universities in terms of development of new and relevant programmes to expand faculties and schools, service to students and quality assurance practices. It can also be concluded from the study that because public universities are service organizations, there is a high level of customer (student) contact and as such service quality and performance could be affected if employees compensate themselves by putting up negative behaviour as a result of inequity in their compensation package. Therefore there is the need for the Government of Ghana who is the employer of these public universities to continue ensures fairness in public sector wage since such inequity can bring a lot of labour agitations which can negatively affect productivity.

\section{Limitation and Recommendations for Further Research}

The study looked at how the removal in disparities of public sector wage in the public universities had influenced employees' behaviour and performance of these universities. The introduction of the SPSS was not only for the employees at the public universities but other institutions in the public sector as well. In light of this, it will be difficult for one to conclude the study by relating to all public sector workers on how the removal in distortions of public sector wage had influenced public sector workers and the performance of the sector. It is therefore recommended that other state owned institutions rather than public universities should be considered for study on the moderating role equity in financial compensation plays between employees' behaviour and the performance of these other state owned institutions.

Again, the study only looked at financial compensation and how it fairness influence employees' behaviour and performance but there are other factors such as organizational policies, leadership styles and non financial compensation that are believed to influence employees' behaviour and performance of organizations. It is therefore recommended that future research should touch on the moderating role these factors play between employees' behaviour and performance of organizations.

\section{References}

Adams, J.S. (1963). Toward an Understanding of Inequity. Journal of Abnormal and Social Psychology, 67, 422-436. https://doi.org/10.1037/h0040968

Carrell, M., \& Dittrich, J. (1978). Equity theory: The recent literature, methodological considerations, and new directions. The Academy of Management Review, 3(2), 202-210.

Geurts S. A., Schaufeli W.B., \& Rutte C.G. (1999). Absence behaviour, turnover intention and per-ceived inequity in the employment relationship. Work and Stress, 13(3), 253-267. https://doi.org/10.1080/026783799296057

Hall, B. (2000). Incentives and controllability: A note and exercise. Harvard Business School Background Note 801-334.

Hopenhayn, H. A (1992). Entry, Exit and Firm Dynamics in Long Run Equilibrium. Econometrica, 60(5), 1127 1150. https://doi.org/10.2307/2951541 
International Monetary Fund 2016, Case studies on managing government compensation and employment", Accessed January 2017, http://www.imf.org/external/pp/ppindex.aspx

Larkin, I., Pierce, L., \& Gino, F. (2012). The psychological costs of pay-for-performance: Implications for the strategic compensation of employees. Strategic Management Journal, 33, 1194-1214. https://doi.org/10.1002/smj.1974

Lazear, E. (2000). Performance pay and productivity. American Economic Review, 90(5), 1346-1361. https://doi.org/10.1257/aer.90.5.1346

Lin,W. H (2000). Study on Influence of Compensation System and Organizational Climate on Job Satisfaction and Job Performance, master's thesis, Graduate Institute of Industrial Engineering, DaYeh University

Lin, Y.P. (2014). Equity Compensation and Organizational Survival: A Conceptual Framework. Journal of Accounting and Finance, 14(4), 141-152.

National Accreditation Board 2017, Accredited Public Universities, Accessed January 2017, www.nab.gov.gh

Osibanjo A.O., Abiodun A.J., \& Fadugba, A.O. (2012). Executive perception of the impact of flexitime on organisational performamce: evidence from the Nigeria Private Sector. International Journal of Applied Behavioural Economics, 1(3), 16-27. https://doi.org/10.4018/ijabe.2012070102

Paik, Y., Parboteeah, K., \& Shim W (2007). The Relationship between Perceived Compensation, Organizational Commitment and Job Satisfaction: The Case of Mexican Workers in the Korean Maquiladoras. International Journal of Human Resource Management, 18(10), 1768-1781. https://doi.org/10.1080/09585190701570940

Seyedian, M., \& Yi, T.D. (2011). Improving financial literacy of college students: A cross-sectional analysis. College Student Journal, 45(1), 177-189.

Zaman, K.H., Shah, S.S., \& Jamsheed, H. (2011). Relationship Between Rewards and Employees Motivation in Non-profit Organisations of Pakistan. Business Intelligence Journal, 4-10.

Zenger, T. (1994). Explaining organizational diseconomies of scale in R\&D: Agency problems and the allocation of engineering talent, ideas, and effort by firm size. Management Science, 40(6), 708-729. https://doi.org/10.1287/mnsc.40.6.708 